\title{
Incidence and risk factors for AIDS-related mortality in HIV patients in China: a cross-sectional study
}

\author{
Hui Zheng ${ }^{1}$, Lu Wang ${ }^{2}$, Peng Huang ${ }^{1}$, Jessie Norris², Qing Wang ${ }^{1}$, Wei Guo ${ }^{2}$, Zhihang Peng ${ }^{1 *}$, Rongbin Yu ${ }^{1}$ \\ and Ning Wang ${ }^{2^{*}}$
}

\begin{abstract}
Background: To estimate the incidence and risk factors for mortality in HIV-1-infected patients in China.

Methods: Information on AIDS-related deaths was collected from the Chinese Center for Disease Control and Prevention's Disease Surveillance Information Reporting System and AIDS Prevention and Control Information System.

Results: A total of 379,348 HIV cases were recorded in the databases from 2006. Among those, 138,288 patients were reported as having developed AIDS and 72,616 (19\%) died of AIDS after data was extracted from the databases in January 2011. Mortality was higher among those patients aged 50 years old or older (AOR: 3.41, Cl: 1.47-7.91) who had been infected by intravenous drug use (AOR: 1.65, Cl: 1.28-2.14) or blood transfusion/donation (AOR: 2.18: 1.18-3.99). Compared to patients who had not initiated highly active antiretroviral therapy (HAART), those who had initiated HAART were more likely to have a long interval of time between infection confirmation and AIDS-related death.
\end{abstract}

Conclusions: The effective reduction of AIDS mortality could be improved through timely treatment.

Keywords: HIV/AIDS, Highly active antiretroviral treatment, Mortality, China

\section{Background}

There are currently an estimated 780,000 people living with HIV in China; at the end of 2011, the cumulative number of reported deaths since the beginning of the HIV epidemic was 93,000 [1]. A report released by the Ministry of Health in 2009 showed that HIV/AIDS had become the leading cause of death from infectious disease in China [2].

The expansion of highly active antiretroviral therapy (HAART) in recent years has offered a hope of preventing thousands of deaths [3-12]. HAART [13] use has notably reduced HIV-related morbidity and mortality in both industrialized and low-income settings since 1996 [4,14-17]. HAART has also contributed additional benefits such as prolonged disease-free survival, durable HIV virologic suppression, immunologic (CD4 cell) repletion, and

\footnotetext{
*Correspondence: zhihangpeng@njmu.edu.cn; wangnbj@163.com 'Department of Epidemiology and Biostatistics, School of Public Health, Nanjing Medical University, Nanjing, Jiangsu 211166, China

${ }^{2}$ National Center for AIDS/STD Control and Prevention, Chinese Center for
} Disease Control and Prevention, Beijing, China reductions in hospitalization rates $[14,18,19]$. As a result of the Chinese government scaling up the National Free Antiretroviral Treatment Programme (NFATP) in 2003, approximately 10,000 people in China were receiving HAART by the end of 2011 [20].

Most previous reports in China have focused on the effects of HAART on clinical and immunologic outcomes compared to those observed in resource-rich settings [21]. Previous studies have already identified that patients starting HAART with low CD4 cell counts have fewer opportunistic infections such as tuberculosis, acute sepsis, cryptococcosis, and toxoplasmosis [22-25]. However, in-depth analysis and systematic research into causes of death among people with HIV/AIDS in China is lacking.

This study presents data from the China Disease Prevention and Control Information System on changes in AIDS mortality through December 31, 2010. It also determines the incidence and related risk factors of mortality following the widespread availability of HAART in China after 2003. 


\section{Methods}

\section{Data collection}

Data on HIV/AIDS patients were collected from the China Disease Prevention and Control Information System. For mortality cases, detailed information was downloaded from the Disease Surveillance Information Reporting System and AIDS Prevention and Control Information System. These databases contain information on patient demographic characteristics, reported provinces of residence, survival time (from diagnosis to death), cause of death, and HAART use. If one case was contained in both databases, we selected the information on the case from AIDS Prevention and Control Information System. All data were assessed from January 1, 2006 to December 31, 2010. HAART was scaled up nationwide in 2003, with data prospectively included in the database after 2004. However, the data collected from 2004 to 2005 covered only part of the provinces, and nationwide collection was not yet initiated; for this reason, the mortality data did not start until 2006.

All records in the databases had undergone quality control, and cases were confirmed in a laboratory. Data were recorded solely for individuals from mainland China, excluding people from Hong Kong, Macao and Taiwan. Non-Chinese citizens were also excluded from our study.

A second analysis was conducted on mortality cases from January 1, 2011 to July 31, 2011. The effects of treatment on death were analyzed by studying the number of days between the date of death and the date of either the first CD4 test or the date of AIDS diagnosis if CD4 test results were unavailable.

\section{Ethics statement}

This study, including design, recruitment, consent, and assessment procedures, was reviewed and approved by the Institutional Review Board of Nanjing Medical University.

\section{Cause of death}

Causes of death for cases reported in the Data Information Management System were verified. Among the 32,562 cases with a cause of death listed as "other reasons", some were confirmed as AIDS-related death by verifying the information filed. When the cause of death was listed as tuberculosis, opportunistic infections (OI), pneumocystis pneumonia (PCP), or AIDS-related disease, the cause of death was reclassified as AIDS. Taking into account that tuberculosis is prevalent in China, those deaths were removed from the analysis of AIDSrelated deaths if the patient's last CD4 did not fall below $200 / \mathrm{uL}$, to avoid overestimating the number of AIDSrelated deaths.

\section{Identify key variables}

A late diagnosis of AIDS-related death was defined as a diagnosis of AIDS (CD4 $<200$ cells/ $\mu \mathrm{L}$ or AIDS-related clinical symptoms) [26] where death occurred within one year after an HIV diagnosis. All patients were eligible for free treatment if their HIV was in WHO clinical stage 3 or 4 , or if they had a CD4 count $<200$ cells $/ \mu \mathrm{L}$ or $<350$ cells $/ \mu \mathrm{L}$ after 2008 . Untreated deaths were defined as patients who died without initiating treatment. Mortality cases with antiviral treatment information in the treatment database were matched to the same cases in the mortality database. The deaths of patients who were not listed in the treatment registry were considered untreated deaths.

\section{Statistical analysis}

SPSS (version 20.0), Stata (version 12.0) and Excel (version 2010) were used for data analysis. Descriptive analyses were conducted to describe mortality cases' characteristics, including mean $( \pm S D)$, median (interquartile range, IQR), and frequencies (\%). A logistic regression was applied to determine the risk factors of HIV/AIDS mortality. Kaplan-Meier survival curves were used to estimate the probability of death and the median time to death after HAART initiation. The log-rank test was used to compare the median time to death between the four groups. Statistical significance was assessed at the 0.05 level, and all hypothesis tests were two-sided.

\section{Results}

\section{General characteristics}

In our study, annual reported deaths from HIV/AIDS from 2006 to 2010 comprised 1809; 5544; 9748; 12,287; and 18,987 cases, respectively. The estimated annual number of new infections was 70,000; 50,000; 48,000; and 48,000 in 2005, 2007, 2009, and 2011, respectively. Based on our data, we estimated the annual mortality rates as being $2.5 \%$ in 2007, 3.5\% in 2008 and $5.0 \%$ in 2010. The actual annual number of HIV/AIDS deaths after verifying cause of death from 2006 to 2010 was 7,013; 9,298; 11,$921 ; 13,832$; and 13,981, respectively, revealing a slower increase than in the data reported. Annual cases of AIDSrelated deaths among actual annual cases from 2006 to 2010 were 2764 ; 3575 ; 4877; and 5675; and 5,793, respectively, showing a relatively slight upward trend.

The total number of deaths in male patients was 54,904. Among all patients, death was more common among those who were $20-49$ years of age $(75.3 \%)$. The median age of death was 38.5 years old, 38.4 years for males and 38.7 years for females. Among self-reported sources of transmission, the proportions of total deaths from infections through heterosexual transmission, injection drug use (IDU), blood transfusion/donation, homosexual transmission and others were $31.7 \%, 28.4 \%, 24.0 \%, 0.8 \%$ and $1.1 \%$, respectively. 
One-fifth (19.7\%) of HIV-infected patients among cumulative deaths reported the use of HAART (Table 1).

The three risk factors most strongly related to mortality were age, not having received HAART and having multiple transmission routes. IDUs (AOR, adjusted odds ratio: 1.65, CI, confidence interval: 1.28-2.14) and blood transfusion/donations (AOR: 2.18, CI: 1.18-3.99) were significantly more likely to having a high mortality compared to those infected through heterosexual transmission; however, the statistical results of individuals infected by homosexual transmission (AOR: 0.33, CI: 0.23-0.47) were just the opposite. Patients aged 50 years old or older (AOR: 3.41, CI: 1.47-7.91) and those who had not received HAART were also significantly likely to have a high mortality. Although sex and marital status were not significantly associated with mortality, female gender and a status of married or divorced had a high risk of mortality in the unadjusted analysis, but these factors were not included in the adjusted analysis (Table 1).

AIDS deaths were reported in the 31 mainland provinces by the end of 2010. The top six provinces with the highest cumulative number of reported HIV/AIDS cases, as well as the highest cumulative number of reported deaths, were Yunnan, Guangxi, Henan, Sichuan, Xinjiang and Guangdong. The top five provinces with the highest proportion of cumulative reported deaths accounting for the cumulative number of reported HIV/AIDS cases were Shanxi, Hubei, Henan, Hebei, and Anhui. The proportion of HIV/AIDS-related deaths was low in provinces such as Beijing, Shanghai, Tianjin, and Zhejiang (Table 2).

\section{Characteristics according to time since HIV diagnosis and HAART}

Among the 72,616 deaths, the median time between diagnosis and death was 0.7 years (IQR: 0.1, 2.6). The median time of HIV infection between diagnosis and death was 0.9 years (IQR: $0.1,2.9$ ). Simultaneously, the median time of AIDS infection between diagnosis and death was 0.6 years (IQR: 0.1, 2.4).

The median time between diagnosis and death for patients receiving treatment was 1.6 years (IQR: 0.44, 3.62 ), while the median time between diagnosis and death for untreated patients was 0.5 years (IQR: 0.1, 2.2).

Table 3 presents and compares the interval between diagnosis and death according to HAART initiation status. The different day ranges between diagnosis and death have different numbers of death, more than 180 days was the most, less than 30 days, 30 to 60 days, 60 to 90 days,

Table 1 Demographics of the actual HIV/AIDS deaths and their associated risk factors from 2006 to 2010

\begin{tabular}{|c|c|c|c|c|c|c|c|c|}
\hline Year & 2006 & 2007 & 2008 & 2009 & 2010 & Total No. (\%) & OR $(95 \% \mathrm{Cl})$ & $\overline{A O R}(95 \% \mathrm{Cl})$ \\
\hline Death & 7013 & 9298 & 11921 & 13832 & 13981 & 72616 & & \\
\hline \multicolumn{9}{|l|}{ Sex } \\
\hline Male & 5167 & 6974 & 9013 & 10688 & 10874 & 54904 (75.6) & 1.0 & 1.0 \\
\hline Female & 1846 & 2324 & 2908 & 3144 & 3107 & $17712(24.4)$ & $1.51(1.22-1.87)$ & $1.02(0.79-1.32)$ \\
\hline Age (median) & 37 & 38 & 39 & 40 & 41 & 38.5 & $1.05(1.04-1.06)$ & $1.03(1.01-1.06)$ \\
\hline $0-20$ & 170 & 226 & 210 & 231 & 214 & $1624(2.3)$ & 1.0 & 1.0 \\
\hline $20-29$ & 1199 & 1455 & 1632 & 1667 & 1589 & $11153(15.4)$ & $0.85(0.41-1.78)$ & $0.89(0.40-1.97)$ \\
\hline $30-39$ & 2817 & 3690 & 4526 & 4870 & 4597 & $27183(37.4)$ & $1.66(0.81-3.41)$ & $1.34(0.61-3.00)$ \\
\hline $40-49$ & 1582 & 2028 & 2755 & 3195 & 3466 & $16365(22.5)$ & $2.02(0.97-4.21)$ & $1.39(0.61-3.19)$ \\
\hline$>50$ & 1244 & 1899 & 2798 & 3869 & 4115 & $16188(22.3)$ & $5.33(2.55-11.15)$ & $3.41(1.47-7.91)$ \\
\hline \multicolumn{9}{|l|}{ Transmission routes } \\
\hline Heterosexual & 1423 & 2509 & 4264 & 5974 & 6796 & 23009 (31.7) & 1.0 & 1.0 \\
\hline IDU & 1872 & 2729 & 3402 & 3784 & 3942 & $20616(28.4)$ & $1.36(1.11-1.68)$ & $1.65(1.28-2.14)$ \\
\hline Blood transfusion/donation & 2288 & 2178 & 2154 & 1513 & 1495 & $17487(24.0)$ & $3.34(1.98-5.61)$ & $2.18(1.18-3.99)$ \\
\hline Homosexual & 22 & 48 & 96 & 151 & 275 & $615(0.8)$ & $0.18(0.14-0.25)$ & $0.33(0.23-0.47)$ \\
\hline Others & 94 & 133 & 113 & 146 & 127 & $792(1.1)$ & $0.77(0.50-1.20)$ & $0.87(0.48-1.56)$ \\
\hline \multicolumn{9}{|l|}{ Marital status } \\
\hline Unmarried & 1386 & 1997 & 2479 & 2843 & 2935 & $14547(20.0)$ & 1.0 & 1.0 \\
\hline Married & 4260 & 5395 & 7093 & 8071 & 7938 & $42239(58.2)$ & $2.43(1.99-2.97)$ & $1.16(0.89-1.50)$ \\
\hline Divorced or widowed & 743 & 1171 & 1536 & 2128 & 2378 & 9109 (12.5) & $2.53(1.95-3.28)$ & $1.12(0.81-1.56)$ \\
\hline \multicolumn{9}{|l|}{ Received HAART } \\
\hline No & 5380 & 7423 & 8945 & 10856 & 10866 & $58318(80.3)$ & 1.0 & 1.0 \\
\hline Yes & 1633 & 1875 & 2513 & 2976 & 3115 & $14298(19.7)$ & $0.41(0.32-0.51)$ & $0.11(0.08-0.14)$ \\
\hline
\end{tabular}


Table 2 The provincial statistics of the cumulative reported cases and the cumulative AIDS-related death cases with HAART

\begin{tabular}{|c|c|c|c|c|c|c|c|}
\hline \multirow[t]{2}{*}{ Province } & \multicolumn{3}{|c|}{ Cumulative reported cases } & \multicolumn{3}{|c|}{ Cumulative death cases } & \multirow{2}{*}{$\begin{array}{r}\text { Proportion o } \\
\text { deaths (\%) }\end{array}$} \\
\hline & Number & Accepted HARRT & Percentage (\%) & Number & Accepted HARRT & Percentage (\%) & \\
\hline Anhui & 6590 & 3564 & 54.1 & 1730 & 446 & 25.8 & 26.3 \\
\hline Beijing & 5259 & 1053 & 20 & 148 & 25 & 16.9 & 2.8 \\
\hline Fujian & 2649 & 710 & 26.8 & 568 & 55 & 9.7 & 21.4 \\
\hline Gansu & 893 & 234 & 26.2 & 163 & 19 & 11.7 & 18.3 \\
\hline Guangxi & 63127 & 16560 & 26.2 & 1359 & 1329 & 9.8 & 21.5 \\
\hline Guangdong & 28534 & 4471 & 15.7 & 5829 & 437 & 7.5 & 20.4 \\
\hline Guizhou & 10290 & 1351 & 13.1 & 1826 & 143 & 7.8 & 17.7 \\
\hline Hainan & 975 & 98 & 10.1 & 292 & 9 & 3.1 & 29.9 \\
\hline Hebei & 1913 & 754 & 39.4 & 607 & 110 & 18.1 & 31.7 \\
\hline Henan & 49325 & 32282 & 65.4 & 1467 & 7471 & 50.9 & 29.7 \\
\hline Heilongjiang & 1571 & 412 & 26.2 & 228 & 34 & 14.9 & 14.5 \\
\hline Hubei & 6613 & 2689 & 40.7 & 2039 & 439 & 21.5 & 30.8 \\
\hline Hunan & 10794 & 2736 & 25.3 & 2831 & 374 & 13.2 & 26.2 \\
\hline Jilin & 1504 & 479 & 31.8 & 387 & 66 & 17.1 & 25.7 \\
\hline Jiangsu & 4084 & 1337 & 32.7 & 643 & 102 & 15.9 & 15.7 \\
\hline Jiangxi & 2556 & 983 & 38.5 & 822 & 169 & 20.6 & 32.2 \\
\hline Liaoning & 2785 & 585 & 21 & 347 & 49 & 14.1 & 12.5 \\
\hline Neimengu & 621 & 119 & 19.2 & 97 & 20 & 20.6 & 15.6 \\
\hline Ningxia & 370 & 77 & 20.8 & 44 & 10 & 22.7 & 11.9 \\
\hline Qinghai & 317 & 98 & 30.9 & 45 & 11 & 24.4 & 14.2 \\
\hline Shandong & 2272 & 754 & 33.2 & 547 & 87 & 15.9 & 24.1 \\
\hline Shanxi & 3055 & 1180 & 38.6 & 1002 & 158 & 15.8 & 32.8 \\
\hline Shanxi & 1569 & 460 & 29.3 & 309 & 72 & 23.3 & 19.7 \\
\hline Shanghai & 5260 & 1154 & 21.9 & 239 & 48 & 20.1 & 4.5 \\
\hline Sichuan & 38356 & 5041 & 13.1 & 5485 & 440 & 8 & 14.3 \\
\hline Tianjin & 885 & 237 & 26.8 & 99 & 22 & 22.2 & 11.2 \\
\hline Tibet & 126 & 8 & 6.3 & 10 & 1 & 10 & 7.9 \\
\hline Xinjiang & 33519 & 4119 & 12.3 & 4107 & 379 & 9.2 & 12.3 \\
\hline Yunnan & 79433 & 18953 & 23.9 & 1222 & 1537 & 12.6 & 15.4 \\
\hline Zhejiang & 4713 & 1695 & 36 & 494 & 88 & 17.8 & 10.5 \\
\hline Chongqing & 9390 & 1603 & 17.1 & 1179 & 148 & 12.6 & 12.6 \\
\hline Nationwide & 379348 & 105796 & 27.9 & 72616 & 14298 & 19.7 & 19.1 \\
\hline
\end{tabular}

90 to 180 days was $15615,5543,4002,7164$, respectively. Among all deaths by the end of 2010, 80.3\% (58318/ 72616) of patients who died did not receive HAART and $75.0 \%$ (43732/58318) of those had no CD4 test result. For those patients with CD4 test results, 62.8\% (9167/14586) had a CD4 count below 200 at their first lab test, and 78.9\% (11643/14586) had a CD4 count below 350 at their first lab test. Compared to patients who had not initiated HAART, those who had initiated HAART were more likely to have a long interval of time between diagnosis and death $\left(\chi^{2}=3621.19, p<0.001\right)$.
According to the AIDS Network Reporting System, by the end of 2010, 56.1\% (40746/72616) of the cumulative number of patients who died were late diagnoses. Of those who died after receiving a late diagnosis, $73.5 \%$ were male, $64.6 \%$ were married, and $74.5 \%$ were ethnically Han. Transmission categories for these deaths included heterosexual transmission (43.4\%), IDU (15.9\%), blood donation (14.4\%), and blood transfusion (8.3\%). Most (61.9\%) patients were first diagnosed in their counties of residence.

Among the patients who died who had never initiated HAART, $77.4 \%$ were male, $55.5 \%$ were married, and 
Table 3 HAART and CD4 test results of the cumulative HIV/AIDS deaths by the end of 2010

\begin{tabular}{|c|c|c|c|c|c|c|c|}
\hline \multirow{3}{*}{$\begin{array}{l}\text { The interval between infection } \\
\text { confirmation and deaths (day) }\end{array}$} & \multirow[t]{3}{*}{ Deaths } & \multirow{3}{*}{$\begin{array}{l}\text { Initiated HAART } \\
\text { No. (\%) }\end{array}$} & \multicolumn{5}{|c|}{ Not receiving HAART } \\
\hline & & & \multicolumn{4}{|c|}{ First laboratory CD4 count } & \multirow{2}{*}{$\begin{array}{c}\text { No CD4 test result } \\
\text { No. (\%) }\end{array}$} \\
\hline & & & $\leq \mathbf{2 0 0}$ & $200-350$ & $>350$ & Total No. (\%) & \\
\hline$<30$ & 15615 & $610(3.9)$ & 1346 & 77 & 61 & $1484(9.5)$ & $13521(86.6)$ \\
\hline $30-$ & 5543 & $788(14.2)$ & 1014 & 77 & 54 & $1145(20.7)$ & $3610(65.1)$ \\
\hline $60-$ & 4002 & $832(20.8)$ & 831 & 52 & 60 & $943(23.6)$ & $2227(55.6)$ \\
\hline $90-$ & 7164 & $1573(22.0)$ & 1400 & 161 & 170 & $1731(24.2)$ & $3860(53.9)$ \\
\hline$\geq 180$ & 40292 & $10495(26.0)$ & 4576 & 2109 & 2598 & $9283(23.0)$ & $20514(50.9)$ \\
\hline Total & 72616 & $14298(19.7)$ & 9167 & 2476 & 2943 & $14586(20.0)$ & $43732(60.2)$ \\
\hline
\end{tabular}

67.3\% were ethnically Han. Transmission categories included heterosexual transmission (33.2\%), IDU (32.0\%), blood donation (11.3\%) and blood transfusion (5.4\%). Most (60.9\%) patients were first diagnosed in their counties of residence (Table 4).

\section{Underlying cause of death}

Out of 72,616 total deaths, there were 63,785 cases with information on cause of death, of which 31,223 (49.0\%) were considered AIDS-related deaths and 32,562 had other causes of death. AIDS deaths accounted for $57.1 \%$ of all deaths after cause of death was verified. Results are shown in Table 5.

\section{Characteristics of treated deaths by baseline CD4 cell counts}

Based on the data collected from January 1, 2011 to July 31,2011 , most of the patients who died without initiating HAART died either more than 12 months from diagnosis $(\mathrm{n}=2,027)$ or less than three months from diagnosis $(\mathrm{n}=2,543)$. More than half $(57.5 \%)$ never received a CD4 test before their death. Among the 2,375 patients who had received a CD4 test, 1,772 had first CD4 test results that met the criteria to initiate treatment. Among 603 patients with CD4 counts $>350$ cells $/ \mu \mathrm{L}, 210(34.8 \%)$ had a subsequent CD4 test with a count $<350$ cells $/ \mu \mathrm{L}$ (Table 6 ).

The probability of survival after receiving HAART is shown by the Kaplan-Meier method in Figure 1. The study population was analyzed in four groups based on baseline CD4 cell counts (Group 1: CD4 count $<50$ cells $/ \mu \mathrm{L}$, Group 2: CD4 count $\geq 50$ cells $/ \mu \mathrm{L}$ and $\leq 200$ cells $/ \mu \mathrm{L}$, Group 3 : CD4 count $>200$ cells $/ \mu \mathrm{L}$ and $\leq 350$ cells $/ \mu \mathrm{L}$, and Group 4 : CD4 count $>350$ cells $/ \mu \mathrm{L})$. Survival rates at 12,36 , and 60 days were $82.1 \%, 75.9 \%$, and $70.9 \%$ in Group 1; $92.6 \%$, $85.8 \%$, and $82.7 \%$ in Group 2; $95.9 \%, 89.6 \%$ and $85.6 \%$ in Group 3; and $96.4 \%, 90.8 \%$ and $87.4 \%$ in Group 4 (log-rank test, $p<0.001)$.

\section{Discussion}

This study showed some notable findings on causes of death among a large and demographically diverse population of HIV patients. Mortality was higher among those patients aged 50 years old or older who had been infected by IDU or blood transfusion/donation and had not accepted HAART.

According to our study, the risk factor strongly related to death was age, especially for individuals aged 50 years old or older. There may be many reasons for this. First of all, a substantial proportion of elderly people who meet treatment criteria may give up treatment voluntarily. This is likely to be associated with the personal characteristics of this group, such as having low levels of education and desiring to reduce the burden on family. Furthermore, individuals in older age groups may be likely to refuse treatment as a result of the stigma associated with HIV/AIDS [27], without the support of social and family members. Last but not least, elderly people may be underserved by the public health system, especially in some less developed areas.

The study noted a significant risk of mortality in individuals who were infected by IDU and blood transfusion/donation compared to heterosexual transmission. IDU was the primary mean of transmission at the beginning of China's HIV epidemic [28], which led to a long period of infection and late treatment initiation. Consequently, those infected by IDU had a higher mortality rate, which is consistent with other reports [29,30]. In addition, the high mortality in IDUs may be associated with personal characteristics; some foreign studies indicated that the majority of accidental deaths among IDUs are from drug overdoses [31,32].

Similarly, blood transfusion was also one of the main routes in the early phase of China [33], most former plasma donors (FPD) or blood receptors infected by HIV long time ago, which made the disease developed long enough to become a danger for bodies and thus a risk factor for higher mortality [34].

Significantly, there is a protective influence in individuals infected by homosexual transmission, in contrast with individuals infected by heterosexual transmission. There may be a bias here due to the database's small sample of men who have sex with men (MSM), although 
Table 4 Demographics of late diagnosis of HIV deaths and untreated deaths by the end of 2010

\begin{tabular}{lccc}
\hline & & $\begin{array}{c}\text { Late diagnosis } \\
\text { of deaths } \\
\text { No. (\%) }\end{array}$ & $\begin{array}{c}\text { Untreated deaths } \\
\text { cases } \\
\text { Sex }(\%)\end{array}$ \\
\hline & Male & & \\
& Female & & \\
Age (years) & & $10954(73.5)$ & $45162(77.4)$ \\
& $0-9$ & $1062(2.6)$ & $634(1.1)$ \\
& $10-19$ & $/$ & $533(0.9)$ \\
& $20-29$ & $5556(13.6)$ & $6339(10.9)$ \\
& $30-39$ & $13709(33.7)$ & $13795(23.7)$ \\
& $40-49$ & $9360(23.0)$ & $8801(15.1)$ \\
50 & $10981(27.0)$ & $10567(18.1)$
\end{tabular}

Marital status

$$
\begin{gathered}
\text { Married } \\
\text { Unmarried } \\
\text { Divorced or widowed }
\end{gathered}
$$

$26336(64.6)$

$32390(55.5)$

$7019(17.2)$

$12518(21.5)$

$5222(12.8)$

$6913(11.9)$

Ethnicity

$$
\begin{gathered}
\text { Han } \\
\text { Zhuang/Wei/Yi/Dai } \\
\text { Other ethnicity }
\end{gathered}
$$

Infection Routes

Heterosexual
IDU
Blood Donation
Blood Transfusion
MTCT
MSM
Sex (both MSM and heterosexual
) + IDU
Unknown

$17693(43.4)$

$6462(15.9)$

$5847(14.4)$

$3391(8.3)$

$510(1.3)$

$453(1.1)$

$283(0.7)$

/

Location of death

Local county

$25309(61.9)$

Local city and other county

Local province and other city

Other province

$8116(19.9)$

5507 (13.5)

$1914(4.7)$

Reporting units

\begin{tabular}{|c|c|c|}
\hline \multicolumn{3}{|l|}{ Occupation } \\
\hline Farmer & $24411(59.9)$ & $31839(54.6)$ \\
\hline Housekeeper and unemployed & $4556(11.2)$ & $9039(15.5)$ \\
\hline Laborer & $2083(5.1)$ & $2784(4.8)$ \\
\hline Retired & $1392(3.4)$ & $1528(2.6)$ \\
\hline Migrant worker & $1308(3.2)$ & $1522(2.6)$ \\
\hline Business & / & $1346(2.3)$ \\
\hline
\end{tabular}

$$
\begin{gathered}
\text { Disease control system } \\
\text { Medical institution } \\
\text { Blood center }
\end{gathered}
$$

Drug addiction treatment facility

$\begin{array}{cc}24833(61.0) & 39862(68.4) \\ 15744(38.6) & 17746(30.4) \\ 26(0.1) & 105(0.2) \\ 53(0.1) & 472(0.8)\end{array}$

Table 4 Demographics of late diagnosis of HIV deaths and untreated deaths by the end of 2010 (Continued)

the population of MSM has begun to increase in recent years in China [35,36]. Another potential reason may be that the majority of MSM are relatively young.

The results of our study reveal a statistically significant difference between accepting HAART or not. The results provide evidence that increasing HAART coverage at the population level can decrease HIV-related mortality, which conforms with the results of overseas findings such as those from the mid-to-late 1990s in the USA [4], Europe [37] and in other earlier studies [38-40].

In the five provinces with the highest proportion of cumulative AIDS deaths, patients who died almost always had a history of paid blood donation. These regions excelled at early detection, management of cases and follow-ups, and reporting deaths. Conversely, in Beijing, Shanghai, Tianjin, and Zhejiang, the proportion of $\mathrm{cu}-$ mulative AIDS deaths was the lowest among all provinces. The reason for the low AIDS deaths in these areas may be due to their large migrant populations, whose high mobility complicates follow-up.

According to previous studies, end-stage patients with low CD4 counts achieve significantly fewer life-prolonging effects through HAART than those with high CD4 counts. However, according to the results of this study, most of those who died before initiating HAART never had a CD4 test. Efforts should be made to improve coverage of HIV diagnostic tests and the frequency of CD4 testing in order to offer timely HAART to prolong survival time. The median time between diagnosis and death was only 0.7 years, and nearly half of cases were discovered late. Though HAART can effectively reduce the fatality rate of HIV/ AIDS, many at-risk individuals do not seek out standard HIV counseling and testing services. The stigmas associated with drug use and HIV/AIDS and the fear of arrest

Table $\mathbf{5}$ Cause of death for HIV cases by the end of 2010

\begin{tabular}{lccccc}
\hline Causes of & \multicolumn{2}{c}{ Original report } & & \multicolumn{2}{c}{ After adjustment } \\
\cline { 2 - 3 } \cline { 6 - 6 } \cline { 5 - 6 } & Number of cases & $\%$ & & Number of cases & $\%$ \\
\hline AIDS & 31223 & 49.0 & & 36438 & 57.1 \\
Other & 32562 & 51.1 & & 27347 & 42.9 \\
Total & 63785 & 100.0 & & 63785 & 100.0 \\
\hline
\end{tabular}


Table 6 CD4 test results for mortality cases from January 1, 2011 to July 31, 2011

\begin{tabular}{|c|c|c|c|c|c|c|}
\hline \multirow{2}{*}{$\begin{array}{l}\text { Interval between death and confirming } \\
\text { (months) }\end{array}$} & \multirow{2}{*}{$\begin{array}{l}\text { Number of } \\
\text { deaths }\end{array}$} & \multirow{2}{*}{$\begin{array}{l}\text { Proportion with at least one CD4 test } \\
\qquad \mathrm{N}(\%)\end{array}$} & \multicolumn{4}{|c|}{ First $\mathrm{CD} 4$ test results } \\
\hline & & & $<50$ & $50-200$ & $201-350$ & $>350$ \\
\hline $0-2$ & 2543 & 567 (22.3\%) & 360 & 145 & 28 & 34 \\
\hline $3-5$ & 457 & 245 (53.6\%) & 124 & 83 & 18 & 20 \\
\hline $6-8$ & 334 & 189 (56.6\%) & 82 & 62 & 15 & 30 \\
\hline $9-11$ & 222 & $120(54.1 \%)$ & 33 & 47 & 11 & 29 \\
\hline$\geq 12$ & 2027 & $1254(61.9 \%)$ & 173 & 274 & 317 & 490 \\
\hline Total & 5583 & $2375(42.5 \%)$ & 772 & 611 & 389 & 603 \\
\hline
\end{tabular}

or of a positive result can be major barriers to accessing HIV voluntary counseling and testing (VCT) services [41]. It is critical to scale up early monitoring to provide prompt treatment and effectively reduce AIDS mortality.

The results of this survival analysis indicate the benefits of HAART in reducing overall mortality and AIDSrelated morbidity, which is similar to results in other studies [42,43]. However, the cumulative number of HIV-positive adults using HAART in China was less than $20 \%$ by the end of 2010 [20]. The results indicate that HIV-positive individuals need to be diagnosed much earlier, which would suggest that HIV testing programs should be expanded.

In our study, survival analysis in HIV patients received HAART also indicated that individuals were more likely to have a long interval of time between diagnosis and death compared to individuals who had high baseline CD4 cell counts. The differences were more visible between Group 1 and Group 4. Timely HAART should be provided to prolong survival time, as receiving HAART is the best way to reduce mortality. Mechanisms should be in place to prevent the development of drug resistance and to enhance clinical services, including implementing viral load testing, increasing adherence, and

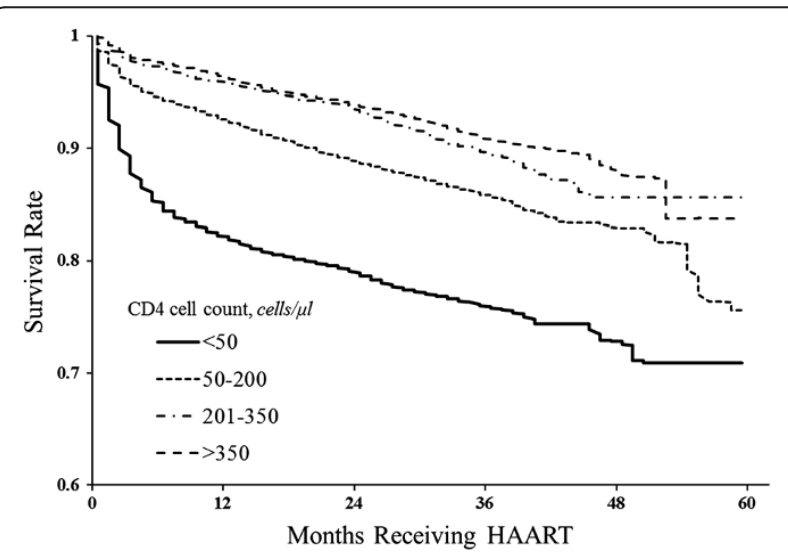

Figure 1 The survival probability for cases receiving antiretroviral therapy, arranged by baseline CD4 cell count. providing prompt second-line therapy for patients with first-line treatment failure.

This study had several limitations. First, data were used from sentinel detection databases and may not be representative of all deaths in China, may exclude those who were homeless or living alone when they died and may underestimate AIDS-related mortality. Second, many could have died of AIDS, but if they were never diagnosed the cause of death could have been listed as something else and they would not be included in the databases. Third, data may have been missing from the databases for other reasons. Missing data may influence the determination of receiving HAART or not, which likely underestimates the proportion of patients who had initiated HAART.

\section{Conclusions}

In summary, early diagnosis of HIV can maximize the effectiveness of HAART. It is essential to continue monitoring HAART uptake and adherence in China, which will help to save lives.

\section{Abbreviations}

HAART: Highly active antiretroviral therapy; NFATP: National Free Antiretroviral Treatment Programme; Ol: Opportunistic infections; PCP: Pneumocystis pneumonia; IDU: Injection drug use; MSM: Men who have sex with men; VCT: Voluntary counseling and testing.

\section{Competing interests}

The authors declare that they have no competing interests.

\section{Authors' contributions}

NW, LW and ZP were involved in the study design. WG and PH performed the experiments. $\mathrm{HZ}$ and $\mathrm{QW}$ analyzed the data. LW and WG contributed reagents/materials/analysis tools. $\mathrm{HZ}$ wrote the paper. All authors read and approved the final manuscript.

\section{Acknowledgements}

The authors are grateful to Professor Rongbin Yu for important suggestions on this research. This work was funded by Natural Science Foundation of China (81001288), National S\&T Major Project Foundation of China (No. 2012ZX10001-001 and No. 2011ZX10004-902), Priority Academic Program Development of Jiangsu Higher Education Institutions (PAPD), Jiangsu Province Health Development Project with Science and Education (NO.ZX201109), and National Science and Technology Support Program (2011BAl09B02). The comments and suggestions from the reviewers are also deeply appreciated. 
Received: 24 February 2014 Accepted: 3 July 2014

Published: 11 August 2014

\section{References}

1. Ministry of Health of The People's Republic of China: 2012 China AIDS Response Progress Report. 2012, http://www.unaids.org/en/dataanalysis/ knowyourresponse/countryprogressreports/2012countries/ ce_CN_Narrative_Report[1].pdf.

2. Jiang $Z S_{\text {, }}$ Jiang JN : Research progress in death risk factors of HIV infector and AIDS patients. Inter J Epidemiol Infect Dis 2012, 39(1):63-67.

3. Walensky RP, Wood R, Weinstein MC, Martinson NA, Losina E, Fofana MO, Goldie SJ, Divi N, Yazdanpanah Y, Wang B, Paltiel AD, Freedberg KA: Scaling up antiretroviral therapy in South Africa: the impact of speed on survival. J Infect Dis 2008, 197(9):1324-1332.

4. Palella FJ, Delaney KM, Moorman AC, Loveless MO, Fuhrer J, Satten GA Aschman DJ, Holmberg SD: Declining morbidity and mortality among patients with advanced human immunodeficiency virus infection. HIV Outpatient Study Investigators. N Engl J Med 1998, 338(13):853-860.

5. The Antiretroviral Therapy Cohort Collaboration: Life expectancy of individuals on combination antiretroviral therapy in high-income countries: a collaborative analysis of 14 cohort studies. Lancet 2008, 372(9635):293-299.

6. Sungkanuparph S, Chakriyanuyok T, Butthum B: Antiretroviral therapy in AIDS patients with CMV disease: impact on the survival and long-term treatment outcome. J Infect 2008, 56(1):40-43.

7. Detels R, Tarwater P, Phair JP, Margolick J, Riddler SA, Munoz A: Effectiveness of potent antiretroviral therapies on the incidence of opportunistic infections before and after AIDS diagnosis. AIDS 2001, 15(3):347-355.

8. Palella JF, Chmiel JS, Moorman AC, Holmberg SD: Durability and predictors of success of highly active antiretroviral therapy for ambulatory HIVinfected patients. AIDS 2002, 16(12):1617-1626.

9. Moore RD, Chaisson RE: Natural history of HIV infection in the era of combination antiretroviral therapy. AIDS 1999, 13(14):1933-1942.

10. Mocroft A, Ledergerber B, Katlama C, Kirk O, Reiss P, D'Arminio MA, Knysz B, Dietrich M, Phillips AN, Lundgren JD: Decline in the AIDS and death rates in the EuroSIDA study: an observational study. Lancet 2003, 362(9377):22-29.

11. Porter K, Babiker A, Bhaskaran K, Darbyshire J, Pezzotti P, Walker AS: Determinants of survival following HIV-1 seroconversion after the introduction of HAART. Lancet 2003, 362(9392):1267-1274.

12. Palella FJ, Baker RK, Moorman AC, Chmiel JS, Wood KC, Brooks JT, Holmberg SD: Mortality in the highly active antiretroviral therapy era: changing causes of death and disease in the HIV outpatient study. J Acquir Immune Defic Syndr 2006, 43(1):27-34.

13. Bozzette SA, Joyce G, Mccaffrey DF, Leibowitz AA, Morton SC, Berry SH, Rastegar A, Timberlake D, Shapiro MF, Goldman DP: Expenditures for the care of HIV-infected patients in the era of highly active antiretroviral therapy. N Engl J Med 2001, 344(11):817-823.

14. Egger M, May M, Chene G, Phillips AN, Ledergerber B, Dabis F, Costagliola D, D'Arminio MA, de Wolf F, Reiss P, Lundgren JD, Justice AC, Staszewski S, Leport C, Hogg RS, Sabin CA, Gill MJ, Salzberger B, Sterne JA: Prognosis of HIV-1-infected patients starting highly active antiretroviral therapy: a collaborative analysis of prospective studies. Lancet 2002, 360(9327):119-129.

15. Mocroft A, Brettle R, Kirk O, Blaxhult A, Parkin JM, Antunes F, Francioli P, D'Arminio MA, Fox Z, Lundgren JD: Changes in the cause of death among HIV positive subjects across Europe: results from the EuroSIDA study. AIDS 2002, 16(12):1663-1671.

16. Murphy EL, Collier AC, Kalish LA, Assmann SF, Para MF, Flanigan TP, Kumar PN, Mintz L, Wallach FR, Nemo GJ: Highly active antiretroviral therapy decreases mortality and morbidity in patients with advanced HIV disease. Ann Intern Med 2001, 135(1):17-26.

17. Zhang F, Dou Z, Ma Y, Zhao Y, Liu Z, Bulterys M, Chen RY: Five-year outcomes of the China National Free Antiretroviral Treatment Program. Ann Intern Med 2009, 151(4):241-251. 52.

18. Fleishman JA, Hellinger FH: Recent trends in HIV-related inpatient admissions 1996-2000: a 7-state study. J Acquir Immune Defic Syndr 2003, 34(1):102-110.

19. Hogg RS, Yip B, Chan KJ, Wood E, Craib KJ, O'Shaughnessy MV, Montaner JS: Rates of disease progression by baseline CD4 cell count and viral load after initiating triple-drug therapy. JAMA 2001, 286(20):2568-2577.
20. Jian L, Ye M, Fu-Jie Z: HIV antiretroviral therapy mode and the current situation in China. Chin J AIDS STD (In Chinese) 2012, 18(10):711-714.

21. Dai Y, Qiu ZF, Li TS, Han Y, Zuo LY, Xie J, Ma XJ, Liu ZY, Wang AX: Clinical outcomes and immune reconstitution in 103 advanced AIDS patients undergoing 12-month highly active antiretroviral therapy. Chin Med J (Engl) 2006, 119(20):1677-1682

22. Etard JF, Ndiaye I, Thierry-Mieg M, Gueye NF, Gueye PM, Laniece I, Dieng AB, Diouf A, Laurent C, Mboup S, Sow PS, Delaporte E: Mortality and causes of death in adults receiving highly active antiretroviral therapy in Senegal: a 7-year cohort study. AIDS 2006, 20(8):1181-1189.

23. Seyler C, Anglaret X, Dakoury-Dogbo N, Messou E, Toure S, Danel C, Diakite N, Daudie A, Inwoley A, Maurice C, Tonwe-Gold B, Rouet F, N'Dri-Yoman T, Salamon R: Medium-term survival, morbidity and immunovirological evolution in HIV-infected adults receiving antiretroviral therapy, Abidjan, Cote d'Ivoire. Antivir Ther 2003, 8(5):385-393.

24. Lawn SD, Bekker LG, Myer L, Orrell C, Wood R: Cryptococcocal immune reconstitution disease: a major cause of early mortality in a South African antiretroviral programme. AIDS 2005, 19(17):2050-2052.

25. Lawn SD, Myer L, Bekker LG, Wood R: Burden of tuberculosis in an antiretroviral treatment programme in sub-Saharan Africa: impact on treatment outcomes and implications for tuberculosis control. AIDS 2006 20(12):1605-1612.

26. Wanyenze RK, Kamya MR, Fatch R, Mayanja-Kizza H, Baveewo S, Sawires S, Bangsberg DR, Coates T, Hahn JA: Missed opportunities for HIV testing and late-stage diagnosis among HIV-infected patients in Uganda. PLoS One 2011, 6(7):e21794.

27. Hosegood V, Vanneste AM, Timaeus IM: Levels and causes of adult mortality in rural South Africa: the impact of AIDS. AIDS 2004, 18:663-671.

28. Ministry of Health of the People's Republic of China: Estimated that China's AIDS epidemic in 2011. Chin J AIDS STD 2012, 18(1):1-5.

29. Wang L, Qin QQ, Ding ZW, Li PL, Hei FX, Wang LY, Chen FF: Current case reporting of HIV/AIDS epidemic in China. Chin J AIDS STD 2011, 17(3):275-278.

30. Zhang FJ, Dou ZH, Ma Y, Zhang Y, Zhao Y, Zhao DC, Zhou ST, Marc B, Zhu $H$, Chen RY: Effect of earlier initiation of antiretroviral treatment and increased treatment coverage on HIV-related mortality in China: a national observational cohort study. Lancet Infect Dis 2011, 11(7):516-524

31. Janssen W, Trubner K, Puschel K: Death caused by drug addiction: a review of the experiences in Hamburg and the situation in the Federal Republic of Germany in comparison with the literature. Forensic Sci Int 1989, 43(3):223-237.

32. Krentz HB, Kliewer G, Gill MJ: Changing mortality rates and causes of death for HIV-infected individuals living in Southern Alberta, Canada from 1984 to 2003. HIV Med 2005, 6(2):99-106.

33. Zhang FJ, Dou ZH, Yu L, Xu JH, Jiao JH, Wang N, Ma Y, Zhao Y, Zhao HX, Chen RY: The effect of highly active antiretroviral therapy on mortality among HIV-infected former plasma donors in China. Clin Infect Dis 2008, 47(6):825-833.

34. Dou ZH, Chen RY, Wang Z, Ji GP, Peng GP, Qiao XC, Fu JH, Meng XD, Bulterys M, Ma Y, Zhao Y, Wang N, Zhang FJ: HIV-infected former plasma donors in rural Central China: from infection to survival outcomes, 1985-2008. PLoS One 2010, 5(10):e13737.

35. Wu Z, Xu J, Liu E, Mao Y, Xiao Y, Sun X, Liu Y, Jiang Y, McGoogan JM, Dou Z, Mi G, Wang N, Sun J, Liu Z, Wang L, Rou K, Pang L, Xing W, Xu J, Wang S, Cui Y, Li Z, Bulterys M, Lin W, Zhao J, Yip R, Wu Y, Hao Y, Wang Y: HIV and syphilis prevalence among men who have sex with men: a crosssectional survey of 61 cities in China. Clin Infect Dis 2013, 58(6):298-309.

36. Guo H, Wei JF, Yang H, Huan X, Tsui SK, Zhang C: Rapidly increasing prevalence of HIV and syphilis and HIV-1 subtype characterization among men who have sex with men in Jiangsu, China. Sex Transm Dis 2009, 36:120-125.

37. Mocroft A, Vella S, Benfield TL, Chiesi A, Miller V, Gargalianos P, d'Arminio Monforte A, Yust I, Bruun JN, Phillips AN, Lundgren JD: Changing patterns of mortality across Europe in patients infected with HIV-1. EuroSIDA Study Group. Lancet 1998, 352:1725-1730.

38. Smit C, Geskus R, Uitenbroek D, Mulder D, Van den Hoek A, Coutinho RA, Prins M: Declining AIDS mortality in Amsterdam: contributions of declining HIV incidence and effective therapy. Epidemiology 2004, 15:536-542.

39. Keiser O, Taffe P, Zwahlen M, Battegay M, Bernasconi E, Weber R, Rickenbach M: All cause mortality in the Swiss HIV Cohort Study from 
1990 to 2001 in comparison with the Swiss population. AIDS 2004, 18:1835-1843.

40. Detels R, Munoz A, McFarlane G, Kingsley LA, Margolick JB, Giorgi J, Schrager LK, Phair JP: Effectiveness of potent antiretroviral therapy on time to AIDS and death in men with known HIV infection duration. Multicenter AIDS Cohort Study Investigators. JAMA 1998, 280:1497-1503.

41. Jiang HY, Fu J, Liu JH, Gong JP, Lu FB: Qualitative study of AIDS-related discrimination among the people with HIV/AIDS. Mod Prev Med (In Chinese) 2010, 37(5):867-875

42. Holtgrave DR: Causes of the decline in AIDS deaths, United States, 1995-2002: prevention, treatment or both. Int J STD AIDS 2005, 16(12):777-781.

43. Li TS: How to improve the anti-HIV treatment success in China. Natl Med J China 2011, 91(21):1441-1442.

doi:10.1186/1471-2458-14-831

Cite this article as: Zheng et al:: Incidence and risk factors for AIDS-related mortality in HIV patients in China: a cross-sectional study. BMC Public Health 2014 14:831.

Submit your next manuscript to BioMed Central and take full advantage of:

- Convenient online submission

- Thorough peer review

- No space constraints or color figure charges

- Immediate publication on acceptance

- Inclusion in PubMed, CAS, Scopus and Google Scholar

- Research which is freely available for redistribution

Submit your manuscript at www.biomedcentral.com/submit
C Biomed Central 